\title{
DETERMINANTS OF PERFORMANCE OF SMALL AND MEDIUM ENTERPRISES MOVING IN THE PROCUREMENT OF GOVERNMENT GOODS AND SERVICES IN BALI PROVINCE, INDONESIA
}

\author{
Sastrawan Kadek Agus*, Utama Made Suyana, Yasa I G.W. Murjana, \\ Purbadharmaja Ida Bagus Putu \\ Faculty of Economics and Business, University of Udayana, Bali, Indonesia \\ *E-mail: kadekajus16@gmail.com
}

\begin{abstract}
Procurement of goods and services by the government now uses an internet-based system where it will open the widest possible access to all businesses throughout Indonesia to compete and compete to become winners including in Bali Province. The change from manual to information technology based is a new challenge to improve performance for Balinese entrepreneurs including SMEs engaged in government goods/services management. The purpose of this study was to analyze the direct influence of the role of government, company size, human capital, social capital and entrepreneurial orientation, on the performance of SMEs engaged in the procurement of government goods / services in Bali, as well as to analyze the indirect influence of company size, social capital, human capital and the role of the government through entrepreneurial orientation towards the performance of SMEs engaged in the procurement of government goods / services in the Province of Bali. The results of research and data analysis show that the role of government, company size, human capital, and entrepreneurial orientation is positive and significant to the performance of SMEs, social capital mediates partially human capital to SME entrepreneurial orientation, social capital does not mediate human capital on SME performance, and orientation entrepreneurship mediates fully with social capital on the performance of SMEs.
\end{abstract}

\section{KEY WORDS}

Performance, social capital, entrepreneurial orientation, human capital, company size, government role.

In the framework of implementing the government, both at the central and regional levels the government has the obligation to provide people's needs in various ways in the form of goods, services and infrastructure development (Simamora, 2009). The government must process the procurement of goods and services with third parties to meet the needs of the community. The implementation of the procurement of goods and services has to be able to provide legal certainty and business certainty and provide protection for Small and Medium Enterprises (SMEs) as an agent of the economy. Nowadays the procurement of goods and services by the government uses an internet-based system where it will open the widest possible access to all businesses throughout Indonesia to compete and compete to be winners including in the Province of Bali. The change from manual to IT-based is a new challenge for the SMEs and its performance in the Province of Bali that are engaged in the procurement of government goods / services.

In terms of business competition and state finance, the procurement of government goods and services is an important sector with the following arguments: First; procurement has a strategic meaning in protection and preference for domestic business actors seen from the amount of budget allocation for procurement of government goods / services that reaches a significant percentage of the State Budget (World Trade Organization Government Procurement, 2005). Every year, the procurement sector spends substantial funds. Second; procurement is a significant sector in efforts to economic growth (Presidential Decree No. 80 of 2003, 2001). Third, the procurement system that is able to apply the principles of good governance will encourage efficiency and effectiveness of public spending as well as the 
three-pillar behavior (government, private sector and society) in the implementation of good corporate governance (Simamora, 2009).

Electronic procurement (E-Procurement) or electronic auction is the process of procurement of goods / services within the scope of government that uses information and communication technology devices in each process and step (Mustafa, 2010). Procurement of goods / services electronically is done by means of e-tendering or e-purchasing which will increase transparency so that fair competition among business actors can more quickly encourage and realize the creation of Open Government discussed earlier (World Bank Draft Strategy, 2003). E-Procurement is an inter-business purchase (business-to-business, B2B) and sales of goods and services through the internet (Australian Government Information Management, AGIMO, 2011), as well as Croom and Jones (2007).

This electronic goods / services auction makes the gateway wide open for thousands of entrepreneurs across the country to take part in government auctions wherever they are. Business competition is getting tougher because the electronic tender process only requires internet access and provides flexibility for all companies in Indonesia and even the world. The challenge for local entrepreneurs has begun but, inevitably, local entrepreneurs must be ready to compete with non-local entrepreneurs. The ability of regional entrepreneurs in competing to win a tender was tested when the increase in competitors from those who had previously come from their own regions now increased competitors from other regions.

With the enactment of e-procurement in the Province of Bali, there is a significant reduction in the rupiah earned by local Balinese businessmen in the procurement of government goods / services every year starting from 2012 to 2015 except in 2013 there was an increase. In 2012 local Balinese businessmen gained 87.5 percent of the total amount of rupiahs being auctioned. In 2013 there was an increase, namely the Balinese businessmen only got 96.07 . Significant decline occurred in 2014, of which the total number obtained by Balinese businessmen was only 70.75 percent and in 2015 Balinese entrepreneurs only got almost half the percentage, 57.11 percent (ULP Bali Province, 2016). Thus it can be said that the changes in the system of procurement of government goods and services have caused local Balinese SMEs to be less competitive compared to outside SMEs. If this continues to cause losses to the regional economy in general, because the existence of SMEs is expected to have a multiplier impact on other sectors, both in the form of added value and labor. Theoretically and empirically the competitiveness of SMEs seen from their performance can be influenced by several factors. Factors that can affect the performance of SMEs between the role of government, company size, human capital, social capital and entrepreneurial orientation. Based on the description above, the purpose of this study was to analyze the direct influence of the role of government, company size, human capital, social capital and entrepreneurial orientation, on the performance of SMEs engaged in the procurement of government goods / services in Bali Province, and to analyze indirect influence of company size, social capital, human capital and the role of government through entrepreneurial orientation towards the performance of SMEs engaged in the procurement of government goods / services in the Province of Bali.

\section{LITERATURE REVIEW}

According to Sumarni (2013), the need for government roles and functions in the economy. Economic development in many countries generally occurs due to government intervention both directly and indirectly. Government intervention is needed in the economy to reduce market failures such as monopoly, price rigidity, and the negative impact of private business activities. The market mechanism cannot function without the existence of rules made by the government. This rule provides the basis for the application of rules of the game, including the provision of sanctions for economic actors who violate them. The role of the government becomes more important because the market mechanism alone cannot solve all economic problems. To ensure efficiency, equity and economic stability, the role and function of the government is absolutely necessary in the economy as a controlling market mechanism. 
The government is very instrumental in empowering SMEs as mandated in Law Number 20 of 2008 concerning Micro, Small and Medium Enterprises. The purpose of empowerment according to this law is to (1) realize the structure of a national economy that is balanced, developing and just; (2) grow and develop the capacity of small and medium micro enterprises to become strong and independent businesses; and (3) increasing the role of small and medium micro enterprises in regional development, employment creation, income distribution, economic growth, and alleviating people from poverty. The government's role also influences entrepreneurship. According to Wahyuni (2008), entrepreneurship begins with the existence of innovations triggered by personal factors and environmental factors. Lack of government support in the implementation of new goods and services procurement systems Local SMEs will be unable to compete with outside SMEs.

Hall Lengnick and Cynthia A. Lengnick Hall (2003) mentions human capital "... is the know-how, skills, and capabilities of individuals in organizations. Reflecting the competencies of human capital people bring to their work. Seeing this understanding, it appears that human capital is an important factor in organizations, because it can make a large contribution to the progress and development of the organization. Furthermore, Becker stated, human capital is that human beings are not just resources but are capital that produces returns and that expenditure made in order to develop the quality and quantity of capital is an investment activity.

According to Fitz-ens (2000) the notion of human capital can be explained as a combination of factors as follows: a) The characteristics of a person he carries from birth to work, intelligence, energy, generally positive attitudes, reliability, commitment, b) A person's ability to learn, talent, imagination, creativity, and what is often referred to as street smart, c) Motivation of someone to share information and knowledge, team spirit and goal orientation. Furthermore Hall (2003) explains it by quoting some of the meanings of human capital as follows: 1) Human capital is "the knowledge, skills and capabilities of individuals that have economic value to an organization" (Bohlander, Snell \& Sherman, 2001), 2) Human capital is the collective value of an organization's know-how. Human capital refers to the value, not reflected in accounting systems, which results from an investment organization must recreate the knowledge in its employees "(Cortada \& Woods, 1999), 3) Human capital is" all individual capabilities, the knowledge, skill, and experience of the company's employee and managers "(Edvinson \& Malone, 1997).

In the era of globalization and the world economy in the current free market, it began to appear increasingly clear that social capital became an important capital. Social capital is the ability of the community to work together to achieve common goals in a group and organization (Coleman, 1988). Therefore it is not wrong if Bourdieu (1986) presents his criticism of the terminology of capital in conventional economics. He stated that capital is not just a means of production, but has a broader understanding and can be classified into 3 (three) groups, namely: (a) economic capital (economic capital), (b) cultural capital, and (c) social capital. Since the first study of social capital was carried out in early 1916 by Lyda Judson Hanifan until the birth of a modern study of social capital in the late 20th century pioneered by Robert D. Putnam, James S. Coleman, and Francis Fukuyama, many definitions were given by experts on social capital (Inayah, 2012). Fukuyama (1995) defines, social capital as a series of informal values or norms that are shared among the members of a group that enables cooperation between them.

Cox (1995) defines social capital as a series of processes of human relations that are supported by networks, norms and social beliefs that enable efficient and effective coordination and cooperation for mutual benefits and virtues. The definition of social capital according to Putnam (1993) is the appearance of social organizations, such as trust, reliability, networks that can improve community efficiency by facilitating coordination and cooperation for mutual benefit. According to Coleman (1988), social capital is an aspect of social structure that facilitates the actions of individuals or corporate actors / companies in social structures. In this case the same as other types of capital, social capital is also productive, which makes achieving individual or company goals will not materialize without the existence of social capital. 
Fukuyama (1999) states that social capital is the ability that arises from the existence of trust and a set of informal values or norms that spread among group members that allow cooperation between them. This collaboration occurs when members of the community meet what is expected between them and believe that others will behave reliably and have honesty. Cohen and Prusak (2001), and Cox Eva (1995) provide a definition that social capital is a series of processes of human relations that are supported by networks, social norms and beliefs that enable efficient and effective coordination and cooperation to gain benefits and virtues together. The ability of business actors is different; this ability is determined by the level of entrepreneurship orientation and business scale that runs from the SME scale to the Big Business, also influenced by many other factors such as educational background, experience, age, ethnicity, family. According to Slater and Narver (1995), a business can reach its full potential of market orientation, when it is caused by the tendency of the nature of entrepreneurial orientation that is appropriate and in accordance with the design and organizational structure. Drucker (2008) argues that entrepreneurial orientation is the nature, character or traits inherent in someone who has a strong will to realize innovative ideas into the real world of business and can develop them strongly.

Entrepreneurial orientation is the ability to create something new and different. The entrepreneurial orientation of an entrepreneur can lead to increased business performance (Covin and Slevin, 1989). Scarborough and Zimmerer (1993) propose the definition of entrepreneurship as follows: someone who creates a new business by considering risks and uncertainties to achieve profit and growth by identifying opportunities and combining them with the resources needed to take advantage of these opportunities.

According to Reswanda (2011), from several opinions about entrepreneurial orientation, the concept of entrepreneurial orientation can be synthesized as a mental attitude, outlook, insight and mindset and pattern of one's actions towards tasks that are their responsibility and are always customer-oriented. Miller and Friesen (1982), Venkatraman and Ramanujam (1986), Lumpkin and Dess. (1996), Ozsomer et al. (1997), Covin and Slevin (2000), Morris and Kuratko (2002), Cooper et al (2004), Robinson and Stern (2007), Frishammar and Horte (2007), and Prince (2012) say that entrepreneurial orientation is formed by the three main dimensions are innovative, proactive and risk taking.

Wedari (2006) in Eka (2010) states that company size is an increase from the fact that large companies will have a large market capitalization, a large book value and high profits. Whereas in small companies will have a small market capitalization, small book value and low profit. According to Ferry and Jones in Sujianto (2001), company size describes the size of a company as indicated by total assets, total sales, average total sales and average total assets. Another study, the size of the company is proxied by the total assets of the company. Total assets are chosen as a proxy for company size by considering that asset values are relatively more stable than market capitalized and sales values (Wuryatiningsih, 2002). According to Analysis (2011), the size of the company has a different influence on the value of the company of a company. If the company has large total assets, the management is more flexible in using the assets in the company. This management's freedom is comparable to the concern that the owner has for his assets. Performance is the result or output of a process (Nurlaila, 2010). According to the behavior approach in management, performance is the quantity or quality of something produced or services provided by someone who does the work (Luthans, 2005). The same thing was stated by Armstrong (1999) that performance is the work of behavior. This definition of performance associates the results of work with behavior. As behavior, performance is a human activity that is directed at implementing organizational tasks assigned to him.

According to Bastian (2006), performance is an illustration of the achievement of an activity, program or policy in realizing the goals, objectives, mission, and vision of the organization. List of what you want to achieve is contained in the strategic planning of an organization. In general, performance is an achievement achieved by the organization in a certain period. According to Neely (2002), performance measurement can be defined as the process of quantifying the efficiency and effectiveness of past actions. The importance of measuring company performance according to Keats and Hitt (1988), that performance 
measurement can be used as a measure of the company's success in a certain period, performance assessment can also be used as feedback for future improvements or improvements in performance. The measurement of company performance referred to in this study is the performance of SMEs as measured by several indicators, namely: sales growth, profit growth, and growth in the number of customers or market share (Zaenal, 2012).

\section{METHODS OF RESEARCH}

This study uses 3 exogenous variables, namely the role of government (PP), human capital (MM), and company size (UK), three endogenous variables, namely: social capital (MS), entrepreneurial orientation (OK), and business performance (UK) Variables of social capital (MS) and entrepreneurial orientation (OK) also act as mediating variables.

Variable Definitions:

- The role of the Government (PP), is the role carried out by the government to empower SMEs with indicators: a) Facilitators, b) Regulators, and c) Catalysts, referenced from Diva (2009);

- Social Capital (MS) is abstract capital owned by SMEs with their communities in order to manage SMEs, with indicators: a) Networks, b) Trust, c) Norms, referenced by Ridell (1997);

- Human Capital (MM) is an asset that has contributions from human resources that play a role in the development and growth of SMEs with indicators: a) Education, and b) Experience, referenced from Maufi (2010);

- Company size (UP) in this study is measured by three indicators: a) Labor, b) Total Debt, and c) Total Assets, referenced from Setiyadi (2007);

- Entrepreneurship Orientation (OK) is the nature, character or characteristics inherent in SME actors in this study measured by three indicators: a) Innovative, b) Proactive, and c) Risk Taking, referenced from Covin and Slevin (1989) and Horte (2007);

- SME Performance (KU), is the result obtained by SMEs in a certain period of time in this study measured by three indicators: a) Sales, b) Profit Growth, and c) Market Sharing, referenced from Zaenal (2012).

All indicators are measured by a Likert scale, using scores from 1 to 5 .

Based on the literature review, a conceptual framework of relationships between variables can be made as shown in Figure 1.

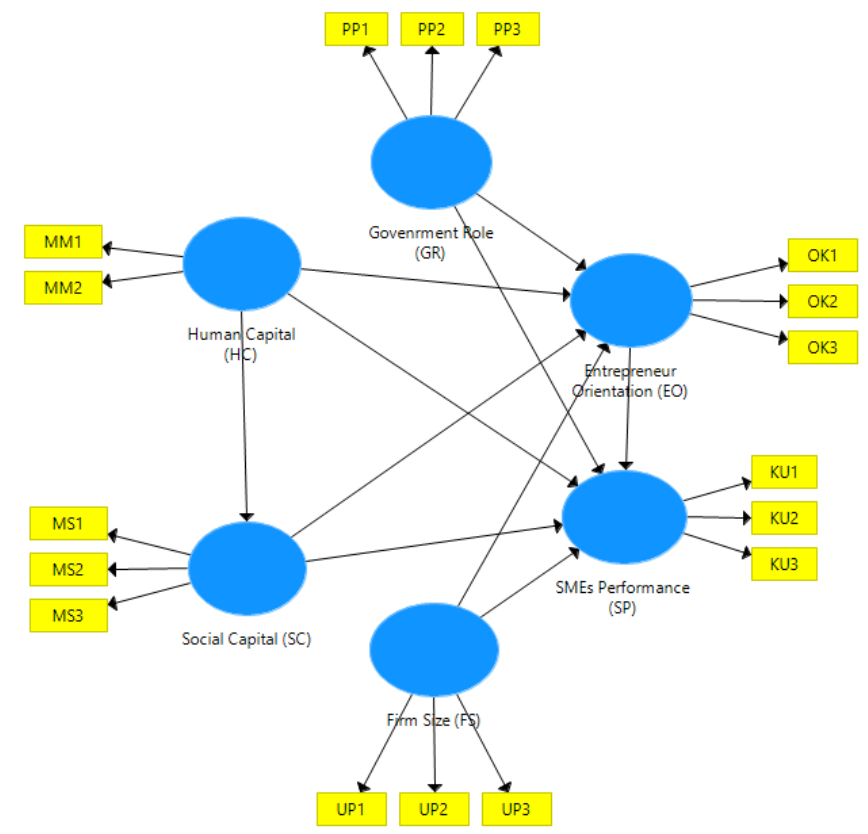

Figure 1 - Relationship of Research Variables Determining the Performance of Small and Medium Enterprises Engaged in the Procurement of Government Goods and Services in Bali Province 
The research data is obtained from primary sources by taking 100 entrepreneurs engaged in goods and services in the Province of Bali conducted in August and September 2017. The method of sampling was carried out using stratified random sampling that met certain criteria: 1) the provider had the qualifications of small and medium enterprises are proven by the ownership of a Trading Business License (SIUP), 2) having participated in an e-procurement with the Bali Provincial Government, and 3) being an active company management both director and company manager. The research data was obtained by structured interviews with respondents using questionnaires, and also conducted by in-depth interviews with several informants.

Data in Likert scale were first tested for validity and reliability. Furthermore, the data was analyzed using structural equation models (SEM) with alternative Partial Least Square or PLS () (Ghozali, 2011). The complete concept of the relationship between variables in this study is presented in Figure 1. Based on Figure 1, using PLS techniques specifies the relationship between variables, including: 1) inner model, 2) outer model, and 3) indirect influence described as follows.

Evaluation of the measurement model or outer model is done according to the shape of the relationship between the indicator and the construct. In the PLS it is known that there are two types of relationships between indicators and their constructs, in this study used a reflective model. The processed data is then evaluated in two stages, namely evaluating the outer model and inner model. The first step is to evaluate the measurement model or outer model which is done according to the type of relationship between the indicator and the construct. The second evaluation is done by looking at the validity of the inner model. In PLS inner model also called inner relations which describe the relationship between latent variables based on the substance of the theory. There are three types of evaluations that are important to the inner model, namely (1) evaluation of goodness of fit, (2) direct influence test, and (3) test of indirect influence or mediation. Before evaluating the inner model, a structural equation system is first made. Based on Figure 2, a structural equation system is made as follows:

Relationship between MM to MS:

$$
M S=\beta_{1} M M+\varepsilon_{1}
$$

Relationship between PP, MM, MS, and UP to OK:

$$
\mathrm{OK}=\beta_{2} \mathrm{PP}+\beta_{3} \mathrm{MM}+\beta_{4} \mathrm{MS}+\beta_{5} \mathrm{UP}+\varepsilon_{2}
$$

Relationship between PP, MM, MS, UP, and OK to KU:

$$
\mathrm{KU}=\beta_{6} \mathrm{PP}+\beta_{7} \mathrm{MM}+\beta_{8} \mathrm{MS}+\beta_{9} \mathrm{UP}+\beta_{10} \mathrm{OK}+\varepsilon_{3}
$$

Where:

$\mathrm{PP}=$ the role of the government; $\quad \mathrm{OK}=$ entrepreneurial orientation;

$\mathrm{MM}=$ human capital;

$\mathrm{KU}=$ business performance;

MS = social capital;

$\beta_{1}, \beta_{2}, \ldots \beta_{10}$ is the path coefficient;

UP = company size;

$\varepsilon_{1}, \varepsilon_{2}, \ldots \varepsilon_{3}$ is error.

\section{RESULTS AND DISCUSSION}

Overall, the full model of the effectiveness of distribution of poor rice in Rasung Regency is presented in Figure 2.

To find out whether the indicator used to form a construct or latent variable is valid, the analysis is carried out as follows.

The results of PLS output regarding convergent validity are shown in Figure 2 . It is known that all indicators have loading values above 0.50 , which means that the constructs made meet the convergent validity requirements. 


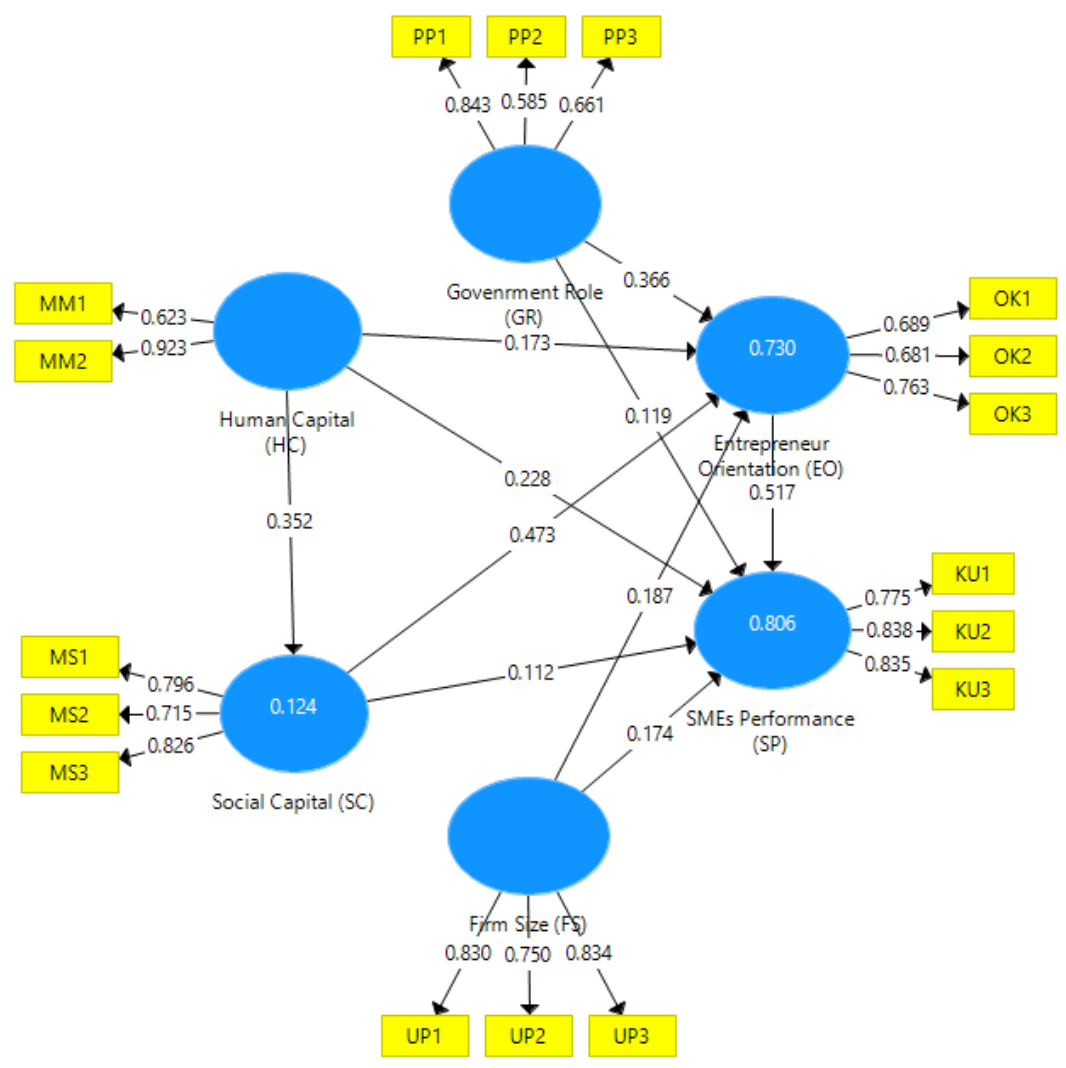

Figure 2 - Full Model of Determinants of Performance of Small and Medium Enterprises in the Government's Procurement of Goods / Services in the Province of Bali

To find out the validity of a construct can also be seen from the discriminant validity. The construct feasibility can also be seen from the discretionary validity (DV) through Average Variance Extracted (AVE), composite reliability $(\rho c)$ generally used for reflective indicators that aim to measure the internal consistency of a construct, and Cronbach Alpha. The processed data shows that all research constructs, namely the role of government, human capital, social capital, company size, entrepreneurial orientation, and SME performance is valid because it has a discretionary validity that is far above 0.70 for Composite Reliability and Cronbach Alpha, and greater than 0.50 for Average Variance Extracted or AVE (Ghozali, 2011).

The inner model test is first done by evaluating the goodness of fit, namely by looking at $\mathrm{R}$ square or R2. For R2 in this study there are two dependent constructs, namely Inclusive Economic Growth (X2) and Community Welfare (Y), as presented in Table 2.

Table 2 - Inner Model Test

\begin{tabular}{lcc}
\hline \multicolumn{1}{c}{ Variable } & R Square & Information \\
\hline 1. Social Capital (MS) & 0,124 & Weak \\
2. Entrepreneurship Orientation (OK) & 0,730 & Strong \\
3. Performance of SMEs (KU) & 0,806 & Strong \\
\hline
\end{tabular}

Table 2 shows that the R-square value of the variable social capital (MS) is 0.124 . Because the R-square value is 0.124 which is less than 0.190 , it means that the influence of human capital on social capital is classified as "weak" according to Chin's opinion (in Ghozali, 2011). The R-square variable of entrepreneurship orientation (OK) is 0.730 , and the performance of SMEs $(\mathrm{KU})$ is 0.806 , values greater than 0.667 are classified as "strong".

Based on the R-square value, the three endogenous variables can be calculated Q2 or Stone-Geiser Q Square tests:

$$
Q^{2}=1-\left\{\left(1-R_{1}^{2}\right)\left(1-R_{2}^{2}\right)\left(1-R_{2}^{2}\right)\right\}=0,954
$$


The results of Q2 or Stone-Geiser Q Square test calculations are equal to 0.954. This value is quite large and can be said to have a high predictive prevalence, so the resulting model is worthy of predicting. The Q2 or Stone-Geiser Q Square test value of 0.954 means that 95.4 percent of the variation in the Business Performance of SMEs Engaging in the Procurement of Government Goods and Services in Bali is explained by variations in the Role of Government, Human Capital, Social Capital, Entrepreneurship Orientation, and Company Size, while the remaining 4.46 percent is explained by other variables not in the model.

The results of testing the significant influence of interconnections are presented in Table 3. From Table 3 all constructs are positively and significantly related to the probability of less than 1 percent. The larger variable influences the welfare of the people in the Regency / City in Bali Province, 2012 - 2017 is inclusive economic growth with a coefficient of 0.604 , while the financial performance is smaller, which is equal to 0.426 .

Table 3 - Path Coefficient Determination of Performance of Small and Medium Enterprises Engaged in the Procurement of Government Goods / Services in the Province of Bali

\begin{tabular}{ccccc}
\hline Variable Relationships & Original Sample & Standard Deviation & T Statistics & $P$ Values \\
\hline MM $\rightarrow$ MS & 0,352 & 0,103 & 3,420 & 0,001 \\
PP $\rightarrow$ OK & 0,366 & 0,062 & 5,865 & 0,000 \\
MM $\rightarrow$ OK & 0,173 & 0,073 & 2,368 & 0,018 \\
MS $\rightarrow$ OK & 0,473 & 0,072 & 6,607 & 0,000 \\
UP $\rightarrow$ OK & 0,187 & 0,079 & 2,365 & 0,018 \\
PP $\rightarrow$ KU & 0,119 & 0,061 & 1,950 & 0,052 \\
MM $\rightarrow$ KU & 0,228 & 0,045 & 5,051 & 0,000 \\
MS $\rightarrow$ KU & 0,112 & 0,073 & 1,524 & 0,128 \\
UP $\rightarrow$ KU & 0,174 & 0,053 & 3,268 & 0,001 \\
OK $\rightarrow$ KU & 0,517 & 0,086 & 6,005 & 0,000 \\
\hline
\end{tabular}

Source: Research data processed.

$P P=$ Role of the Government $; \quad O K=$ Entrepreneurial Orientation;

$M M=$ Human Capital; $\quad U P=$ Company Size;

$M S$ = Social Capital; $\quad K U=S M E$ performance.

Based on Table 3, it can be explained that human capital has a positive effect on social capital with P. Value of 0.001 . The role of government, human capital, social capital, and company size has a positive effect on entrepreneurial orientation with $\mathrm{P}$. Value less than 0.05 . The role of government, human capital, company size, and entrepreneurial orientation has a positive effect on the performance of SMEs with P. Value of less than 0.05 , while social capital though has a positive effect on SME performance, but not significantly, because $P$. value is 0.128 . Based on Table 4 , it can also be seen that the variables that most influence the entrepreneurial orientation are social capital, namely the path coefficient of 0.473 , then followed by the role of government, while the smallest is human capital. The variable that has the greatest influence on the performance of SMEs is entrepreneurial orientation with a path coefficient of 0.517 , while the smallest is social capital with a coefficient of 0.112 .

Table 4 - Indirect Effects Value of Determination of Performance of Small and Medium Enterprises in the Field of Government Goods / Services Procurement in Bali Province

\begin{tabular}{cccccc}
\hline Variable Relationships & Through Variables & Original Sample & Std. Deviation & T. Statistics & P. Value \\
\hline MM $\rightarrow$ OK & MS & 0,166 & 0,048 & 3,465 & 0.001 \\
PP $\rightarrow$ KU & OK & 0,189 & 0,053 & 2,565 & 0.000 \\
MM $\rightarrow$ KU & MS, OK & 0,215 & 0,050 & 4,323 & 0.000 \\
MS $\rightarrow$ KU & OK & 0,245 & 0,054 & 4,559 & 0.000 \\
UP $\rightarrow$ KU & OK & 0,097 & 0,044 & 2,217 & 0,027 \\
\hline
\end{tabular}

Source: Research data, processed.

$P P=$ Role of the Government; $\quad O K=$ Entrepreneurial Orientation;

$M M=$ Human Capital;

$U P=$ Company Size;

MS = Social Capital

$K U=S M E$ performance. 
The indirect effect of an exogenous variable with endogenous variables in this study is presented in Table 4. Based on Table 4 it can be seen that the variable social capital indirectly affects the orientation of entrepreneurship through social capital with $P$. Value of 0.001 , the role variable of government, human capital, and social capital has an indirect effect on the performance of SMEs through an entrepreneurial orientation with $\mathrm{P}$. Value of 0,000 , while the size of the company indirectly influences the performance of SMEs through an entrepreneurial orientation with P. Value of 0.027.

\section{DISCUSSION OF RESULTS}

The Influence of Human Capital on SME Human Capital in the Procurement of Government Goods and Services in the Province of Bali. The results of the research and data analysis show that human capital has a positive and significant effect on the social capital of SMEs engaged in the procurement of government goods / services in the Province of Bali. This means that if human capital increases, the social capital of SMEs also increases. This is in accordance with the opinion of Widodo (2009), that the latest developments in social capital concluded that the value of human capital can be increased through willingness and goodwill built with a series of social relations that can be done to facilitate collective action. Quality human capital and based on strong social capital can be predicted to improve performance.

Some studies show that group learning can improve the results of group work and feeling united in the organization (Cunningham, 2002). For example, the results of observations on the impact of the Leadership Development Program (LDP) at PT. Caltex Pacific Indonesia a few moments after the LDP program was implemented showed a strengthening of social capital. Fellow members of the company feel more familiar and see others as part of the company's success. Afiatin (2003) reported various research results that looked at the impact of using outbound training for personality development that fosters human capital. In addition, Johnson \& Johnson found that being in training has nurtured a sense of community life (Ancok, 2002). This study is not in accordance with the research of Piazza-Georgi (2002) which concluded that investment in human capital will cause a loss of social capital because it cannot stand alone, because one cannot invest together well in the form of capital.

Influence of the Role of Government, Human Capital, Social Capital, and Company Size on SME Entrepreneurship Orientation in the Procurement of Government Goods and Services in the Province of Bali. The results of research and data analysis show that the role of the government has a positive and significant effect on the entrepreneurial orientation of SMEs engaged in the procurement of government goods / services in the Province of Bali. This means that if the role of the government increases in empowering SMEs, then the SME entrepreneurial orientation will also increase. Empowerment provided by the government in the context of business empowerment has been able to foster the innovation of SME Procurement of Goods / Services in Bali Province to win the competition in the government tender process.

The results of this study are consistent with the research of Hadiyati (2011), that the government's efforts to maintain the growth of MSMEs have resulted in two strategic programs, namely entrepreneurship programs and partnership programs. The entrepreneurship program will be the basis for developing human resources. As the results of Wahyuni's (2008) study, that entrepreneurship begins with the existence of innovations triggered by personal factors and environmental factors. Personal factors that influence entrepreneurship are education, experience, commitment, vision, courage to take risks, and age. Environmental factors are sociology, organization, family, opportunities, competitors, investors, and government policies.

This research supports the research conducted by Chen (2006) which states that the government must play an important role in protecting micro, small and medium enterprises to make it develop in a competitive environment with big business. The study also supports the research conducted by Chowdhury (2007) in Bangladesh which concluded that the role of 
government is needed in aspects of political stability and law enforcement, infrastructure improvement, corruption prevention, education and training for entrepreneurs, and financial support with the aim of encouraging entrepreneurship.

The results of research and data analysis show that human capital has a positive and significant effect on the entrepreneurial orientation of SMEs engaged in the procurement of government goods / services in the Province of Bali. This means that if the quality of human capital increases, the SME entrepreneurial orientation will also increase. Education and experience that are part of human capital are things that greatly influence the entrepreneurial orientation, especially the entrepreneurial orientation of SME entrepreneurs in the field of procurement of government goods and services where Mosher (1967) states that the higher the formal education experienced by a person, the level of knowledge and skills the higher, as well as the more open his attitude towards new technology so that the procurement of government goods and services that were previously manual has now shifted to electronics through the internet.

The results of this study are in line with Arrow's statement in Hubbard, O'Brien, and Rafferty (2012) that the development of human capital can be done through various experiences that are passed on by someone. This research is also in accordance with Suparta's (2005) study, which states that education levels greatly determine a person's ability to make decisions, so they could create something.

This study also has similarities with the research of Bianchi (2001) where the results of the study explain that human capital that is specific to an industry plays an important role in producing innovative activities in an industry if this is characterized as a form of transaction or exchange of knowledge high quality among the main players in an industrial environment.

The results of the research and data analysis showed that social capital had a positive and significant effect on the entrepreneurial orientation of SMEs engaged in the procurement of government goods / services in the Province of Bali. This means that if social capital increases, the SME entrepreneurial orientation will also increase. Social capital can be explained as a product of human relations with each other, especially intimate and consistent relationships. Social capital refers to networks, norms and beliefs that have the potential to productivity. However, social capital is different from financial capital, because social capital is cumulative and self-reinforcing (Putnam, 1993). Therefore, social capital will not run out if used, but increases. Unlike human capital, social capital also refers to the ability of people to associate with others (Coleman, 1988). Relying on shared norms and values, the association between humans produces trust which in turn has a large and measurable economic value (Fukuyama, 1995). Social Capital is not only built by one individual, but will lie in the tendency to grow in one community group to socialize in the form of participation as an important part of inherent values (Hasbullah, 2006).

The tight level of tender competition forces SMEs to procure goods and services in Bali to get out of the nest to establish business networks with large distributors. The working philosophy of the competitive and unyielding people of Bali helps Balinese entrepreneurs compete in the procurement of government goods and services. According to Geriya (1995) states that Balinese in conducting business activities, Balinese people are said to have a high work ethic seen from the orientation of Balinese cultural values that are essentially work, both in terms of family life, economic, social, and religious tend to be mostly oriented on the work. Murjana (2005) states that one clear concession related to Balinese behavior in the context of enthusiasm for progress is the competitive spirit that in daily life this competitive spirit is motivated by conception of embarrassment. Jengah has the connotation of competitive spirit, competitive pride, in creating high-quality works. According to Mantra (1990), embarrassment is the dynamic traits possessed by culture, namely a spiritual movement that becomes the base of all changes in people's lives. Balinese embarrassment has the connotation of competitive spirit, competitive pride in the sense of competitiveness is very closely related to the courage in taking risks (risk taking) when competing in the procurement of goods / services of the government, dare to bid responsively with all risks that must be borne by calculation precision. 
This study supports the research conducted by Farsi and Najmabadi (2013) who conducted a study of executive managers of vehicle parts factories in Iran by using 225 samples where the result was that social capital had a positive effect on the entrepreneurial orientation of the executive managers. Social capital is the best foundation for entrepreneurial development and facilitates the interests of employers in facing competition (Huang and Wang, 2011; Huang et al., 2010; Kaasa, 2009; Chisholm and Nielsen, 2009). This research is in line with Wimba's research (2015) which states that social capital directly has a positive and significant effect on entrepreneurial orientation. This study also supports the research conducted by Eraydin and Bilge (2005), that networking and innovation are very important things that provide competitive capability in industrial clusters in the process of globalization.

The results of the research and data analysis showed that the size of the company had a positive and significant effect on the entrepreneurial orientation of SMEs engaged in the procurement of government goods / services in the Province of Bali. This means that if the size of the company increases, the SME entrepreneurial orientation will also increase. According to Ferry and Jones in Sujianto (2001), if the company has large total assets, management is more flexible in using the assets in the company. The limited resources in SMEs can be compensated by the various advantages possessed by SMEs namely flexibility, agility, and the ability to create innovations (Acs and Yeung, 1999, Qian and Li, 2003). Larger companies that have greater and more complete resources than small businesses are easier to deal with changes in the company's life cycle (Miller and Friesen, 1984). This research is in accordance with the study of Baldwin et $a$. $L$ (2000) who found a difference in innovative capabilities in large and small companies. Large companies are more innovative than small ones, because they have easy access to funds to carry out the innovation process.

Effect of the Role of Government, Human Capital, Social Capital, Company Size, and Entrepreneurial Orientation on the Performance of SMEs in the Procurement of Government Goods and Services in the Province of Bali. The results of research and data analysis show that the role of the government has a positive and significant effect on the performance of SMEs engaged in the procurement of government goods / services in Bali Province, indicating that the role of the government can specifically improve the performance of SMEs engaged in the procurement of goods / services. The role of the government in improving the performance of SMEs in the procurement of goods / services is to provide socialization, managerial technical guidance, and increase understanding of applicable policies and regulations.

The results of this study are in accordance with Todaro (2000) which states that the importance of the role of government / public sector as outlined in the formulation of public policies as well as possible presents a series of economic, social and institutional transformations that have a positive impact on the condition of society. Because according to Kuznets as quoted by Jhingan (2000), that economic growth in a nation's economic growth can be seen from the continually increasing supply of goods.

The results of this study are different from the results of the study of Schiffer and Weder (2001) stating that government regulations often hamper SMEs in carrying out their business. This study supports the research conducted by Munizu (2010) entitled The Effect of External and Internal Factors on the Performance of Micro and Small Enterprises (MSEs) in South Sulawesi concluded that external factors consist of aspects of government policy, socio-cultural and economic aspects, and aspects of the role of related institutions have a positive and significant influence on the performance of micro and small enterprises. This research is not in line with Abdullah's (1999) study which found that the government's support policy for SMEs in Malaysia was ineffective with limited reach.

The results of research and data analysis show that human capital has a positive and significant effect on the performance of SMEs engaged in the procurement of government goods / services in Bali which means that if human capital increases, the performance of SMEs also increases. When viewed from the respondents 'perceptions of the highest 
response variable human capital is expressed in education indicators, and the respondents' perceptions are lowest on experience indicators.

The positive influence of human capital on the performance of SMEs in accordance with the opinion of Mosher (1967) which states that, the higher the formal education experienced by a person, the higher the level of knowledge and skills, and the more open attitude towards new technology. This study is also in accordance with the statement of Suhardiyono (1992) that the more non-formal education that respondents have participated in, the more they will increase their knowledge and skills.

The results are also in line with Arrow's statement in Hubbard, O'Brien, and Rafferty (2012) that the development of human capital can be done through various experiences that someone goes through. Experience becomes a learning process to master a skill. The results of this study are also in accordance with the research of Suparta (2005) which says the level of education greatly determines a person's ability in decision making, so that they could create something. Furthermore, it is said that the level of education influences its innovation, the speed of the process of adopting innovation and one's behavior. Mardikanto (1993) also states that education can cause someone to be more open and behave, easier to accept new technology. Those with higher education will be relatively quick to apply innovation, and vice versa, those with less education are rather difficult to implement this innovation quickly (Soekartawi, 1988).

The results of the research and data analysis show that social capital has a positive effect, but not significantly on the performance of SMEs engaged in the procurement of government goods / services in Bali Province so that social capital is less able to specifically improve the performance of SMEs engaged in the procurement of goods / services. In government goods / services providers reflected most dominantly by the norm indicator, followed by network indicators, the respondents' perceptions were lowest on the trust indicator. The results of this study are not in accordance with the opinion of Putnam (1993), that the existence of social capital is indeed different from other capital, such as financial capital or human capital. Fukuyama (1995) states that by relying on shared norms and values, the association between humans will produce trust which ultimately has a large and measurable economic value.

The positive influence of social capital on the performance of SMEs supports the research of Durojaiye et al (2013) conducting research to find out the effect of social capital on profit growth in the food trade business in Nigeria. The results of this study show that social capital plays a positive and significant role in increasing profits in selling makakan materials in Nigeria. Likewise, according to Tri Rahmawati and Hikmah (2010) who conducted a study of the factors that influence the performance of MSMEs in Semarang City concluded that social networks were one of the main factors besides other factors that influenced the performance of MSMEs in Semarang City.

The results of the research and data analysis show that the size of the company has a positive and significant effect on the performance of SMEs engaged in the procurement of government goods / services in the Province of Bali, meaning that if the size of the company increases, the performance of SMEs will also increase. The company size indicators in this study are: labor, total debt, and total assets. The results of this study are in accordance with the theory presented by Acs and Yeung (1999) and Qian and Li (2003) that the limitations associated with resource support for SMEs can be compensated by the various advantages possessed by SMEs namely flexibility, agility, and ability to create innovation. This research is also in accordance with Mutchler's (1985) research in Alexander (2004). Lin (2006) and Wright et al. (2009) found that company size had a positive effect on performance. This shows that large companies are more promising good performance (Lin, 2006).

The results of the research and data analysis showed that entrepreneurial orientation had a positive and significant effect on the performance of SMEs engaged in the procurement of government goods / services in the Province of Bali. This means that if the entrepreneurial orientation increases, the performance of SMEs also increases. The indicators of entrepreneurial orientation used are entrepreneurs who have characteristics: innovative, proactive, and risk taking. The results of this study are in accordance with that 
conveyed by Suryana (2006) that entrepreneurship is called a spearhead (pioneer) to realize a sustainable and highly competitive company economic growth. Innovation capabilities are related to the perception and activity of new and unique businesses. Microactivity in business activities, the company has carried out entrepreneurial activities that will automatically encourage high performance (Weerawardena, 2003). Companies with high entrepreneurial activities mean that they are seen from the high level of enthusiasm that never goes out due to obstacles, obstacles, and challenges or facing risks. A person who takes risks can be defined as someone who is opportunity oriented in the uncertain context of decision making.

The influence of entrepreneurial orientation on the performance of SMEs engaged in the procurement of government goods / services in Bali Province means that entrepreneurial orientation is very necessary and meaningful for SMEs engaged in the procurement of government goods / services in the Province of Bali. This is in line with the expectations of Engkoswara (1999) stating that Indonesia's human life towards the year 2020 will improve and be dynamic. Through individual development it is expected that overall the community will experience "self empowering" to be more creative and innovative.

The results of this study support the research of Wolff and Pett (2006), that entrepreneurial orientation has become a very important variable for the company. Companies with a higher level of entrepreneurial characteristics have a higher level of performance and growth, because they can deal with environmental dynamics more successfully. The results of this study are in line with Covin and Slevin's (2006) research which also confirms the same relationship in both large companies and SMEs. This study supports the research of Frishammar and Horte (2007), that innovation has a positive effect on business performance. This research is also in line with the results of research conducted by Zahra and Garvis (2000), Ireland et all (2003), Wiklund and Stepherd (2005) who found that entrepreneurial orientation had a positive and significant effect on company performance.

Indirect Effects of the Government's Role, Social Capital, Human Capital, Company Size on the Performance of SMEs in the Government's Procurement of Goods / Services in the Province of Bali Through an Entrepreneurial Orientation. Statistically the results of the data study show that there are indirect effects of the role of government, social capital, human capital, the size of the company on the performance of SMEs engaged in the procurement of government goods / services in the Province of Bali through entrepreneurial orientation. For exogenous variables the role of government, human capital, and company size the role of entrepreneurial orientation is categorized as "partial mediation", whereas for social capital variables entrepreneurial orientation is categorized as "full mediation", because previously the direct influence of social capital on SME performance was not significant. The indirect influence of the role of government, social capital, human capital, and company size on the performance of SMEs engaged in the procurement of government goods / services in the Province of Bali through entrepreneurial orientation indicates that the role of government, social capital, human capital, and company size causes orientation entrepreneurship is increasing, further increasing entrepreneurship orientation has increased the performance of SMEs engaged in the procurement of government goods / services in Bali.

The results of this study in accordance with those conducted by Hadiyati (2011) concluded that the government's efforts to maintain the growth of MSMEs have resulted in two strategic programs, namely entrepreneurship programs and partnership programs. Companies with entrepreneurial orientation levels that are high in three dimensions innovative, proactive and risk taking make it possible to identify and utilize opportunities that arise in the corporate environment and build entrepreneurial strategies that lead to company growth (Davis et.al, 2010).

This research supports the research conducted by Usvita (2014) who in Padang City concluded that entrepreneurial orientation had a significant effect on company performance. This study does not support research conducted by Korry et al. (2013) which concluded that entrepreneurial orientation mediates insignificantly the relationship between government policy and the performance of village unit cooperatives in Bali Province. 
The influence of social capital on the performance of SMEs is inseparable from the role of entrepreneurial orientation of SMEs that are engaged in the Procurement of Government Goods / Services in the Province of Bali. The results of this study indicate that with the operation of social capital well, it will enhance the entrepreneurial orientation of SMEs engaged in the Procurement of Government Goods / Services in the Province of Bali. Research by Lee et al. (2007) in leading industries in Taiwan place social capital as a variable that moderates the relationship between entrepreneurial orientation and company performance. His research results show that high social capital will strengthen the relationship between entrepreneurial orientation and performance.

The results of Ahuja's (2000) study state that social capital in the form of networks can increase innovation (as an element of entrepreneurship) that will improve performance. The network will have short-term and long-term welfare implications through processes of innovation, partnerships and new product development (Grave, 2003). Trust is also an element of social capital which has an important influence. The results of Kate and Durance's study (2008) state that social capital in the form of trust will help protect those who will increase innovation, then performance will be more effective.

The indirect influence of human capital on the performance of SMEs, means that human capital has a significant and positive effect on the performance of SMEs inseparable from the entrepreneurial orientation of SMEs engaged in the Procurement of Government Goods / Services in the Province of Bali. The results of this study indicate that with the strengthening of SME Procurement of Goods / Services human capital, it will enhance entrepreneurial orientation in SMEs, to improve the performance of SMEs engaged in the Government Procurement of Goods / Services in the Province of Bali. Increasing the knowledge and skills of employees through training activities is very important in improving company performance. Preffer (1994) and Upton (1995) state that the success of a company in facing market competition is determined by human capital, not physical capital, so that companies are encouraged to invest in various trainings to improve knowledge resources, expertise and employee capabilities better than their competitors.

Some research results explain that there is an influence between entrepreneur orientation and the success of SME businesses. This was stated by many researchers including Lee and Tsang (2001) who examined the impact of entrepreneurial orientation on "venture growth" (Growth of Sales and Profit). Steward et al (2003) also examined aspects of entrepreneurship with elements (1) achievement (2) innovation and (3) risk towards the goal orientation by comparing between entrepreneurial attitudes in the USA compared to entrepreneurial attitudes in Russia. Likewise, Vitale, Giglierano and Miles (2003) examined the effect of entrepreneurial orientation consisting of elements (1) innovating (2) acting proactively and (3) managing risk on performance or growth. Zahra and Covin (1995) suggest that the dimensions of entrepreneurial orientation are independent dimensions and have a positive effect on financial performance.

The results of the research and data analysis show that the size of the company indirectly influences the performance of SMEs through entrepreneurial orientation in SMEs engaged in the Procurement of Government Goods / Services in the Province of Bali. Large companies are considered more innovative because they have the ease of accessing funds to carry out the innovation process. Baldwin, Hanel, and Sabourin in Rahab et al. (2009) found that larger companies will be more innovative than smaller companies, because they have more ease of access to finance, can spread innovation fixed costs to larger sales volumes, benefits derived from economies of scope, and complement each other between activities research and development with other activities.

\section{CONCLUSION}

Based on quantitative and qualitative analysis, as well as the discussions conducted, it can be concluded as follows:

- Human capital is capable of significantly increasing the social capital of SMEs engaged in the procurement of government goods / services in the Province of Bali. 
This shows that education and experience possessed by SMEs can increase their social capital both in terms of networks, norms and beliefs;

- The role of government, company size, human capital, and social capital directly has a positive and significant influence on the entrepreneurial orientation of SMEs engaged in the procurement of government goods / services in the Province of Bali. This means that regulation and empowerment by the government can improve entrepreneurial orientation. The same thing when having high education and experience, trusting each other, upholding good norms, and having a larger company size can increase its entrepreneurial orientation;

- The role of government, company size, human capital, and entrepreneurial orientation is positive and significant towards the performance of SMEs engaged in the procurement of government goods / services in the Province of Bali. If the role of the government, company size, human capital and entrepreneurial orientation is getting better, then the performance of SMEs engaged in the procurement of government goods / services in Bali Province will also increase. Direct social capital has a positive effect, but not significantly on the performance of SMEs;

- There is an indirect influence of the role of the government, social capital, human capital, the size of the company on the performance of SMEs engaged in the procurement of government goods / services in the Province of Bali through entrepreneurial orientation.

\section{SUGGESTIONS}

Based on the background, it was stated earlier that the implementation of eprocurement caused UKM to procure goods / services in Bali Province to be unable to compete with outside business in Bali, so this opportunity was suggested to the Regional Government of Bali Province to always provide empowerment to SMEs procurement of goods / services not only on official forums and official government websites but also cooperating with social media such as Facebook, Instagram and other social media so that access to information on procurement of government goods / services can be widely known by the public and entrepreneurs. Accelerate the implementation of e-catalogs for local products produced by SMEs in the Province of Bali, so that they can be marketed more broadly to increase the competitiveness of local Balinese SMEs.

After analyzing the results of the study, it is known that this study has limitations that the role of government in this research is seen in terms of the role of government in the field of procurement of government goods and services. There are still other government roles, such as the role of government in general in the economic field, namely: the role of resource allocation; the role of social welfare; and the role of managing macroeconomics.

\section{REFERENCES}

1. Abdullah, S. 1999. "Analisis Hubungan Rasio-rasio Keuangan Perusahaan Manufaktur dengan Pemilihan Metoda Persediaan: Studi Kasus di Indonesia," Jurnal Managemen \& Bisnis, vol. 1, no.2. pp. 60-74.

2. Acs, Z. J., and B. Yeung. 1999. Conclusion, "in Small and Medium-Sized Enterprises," in the Global Economy. Ann Arbor: University of Michigan Press.

3. Afiatin, Tina. 2003. "Pengaruh Program Kelompok AJl dalam Peningkatan Harga Diri, Asertivitas and Pengetahuan Mengenai Napza untuk Prevensi Penyalahgunaan Napza pada Remaja". Disertasi. Yogyakarta: UGM.

4. Agus Eko Sujianto. 2001. Analisis Variabel-variabel yang Mempengaruhi Struktur Keuangan Pada Perusahaan Manufaktur yang Go Publik di Bursa Efek Jakarta. Jurnal Ekonomi and Bisnis. Vol 2, No 2.

5. Alexander, Ramadhany. 2004. "Analisis Faktor-Faktor Yang Mempengaruhi Penerimaan Opini Going Concern Pada Perusahaan Manufaktur Yang Mengalami 
Financial Distress di BEJ". Semarang: Thesis Program Magister Akuntansi. Universitas Diponegoro.

6. Ancok, Djamaludin. 2002. Outbond Management Training. Jogjakarta: UII Press.

7. Australian Government Information Management Office (AGIMO). 2011. Commonwealth Electronic Procurement. Implementation Strategy. Canberra: AttorneyGeneral's Department.

8. Ayda, Eraydin \& Bilge Armatli-Koronglu.2005. "Innovation, Networking and New Industrial Clusters"; Entrepreneurship \& Regional Development. Volume 7, Issue 4.

9. Ayu, Sri Mahatma Dewi, Ayu Wirajaya. 2013. Pengaruh Struktur Modal, Profitabilitas and Ukuran Perusahaan Pada Nilai Perusahaan. E-Jurnal Akuntansi Universitas Udayana 4.2.

10. Baldwin, John R. 1999, "Innovation, Training and Succes", Working Paper Series. MicroEconomic Analysis Division Canada, No. 137.

11. Bastian, Indra. 2006. Akuntansi Sektor Publik: Sebuah Pengantar. Jakarta: Penerbit Erlangga.

12. Bianchi, T. 2001." With and without co-operation: two alternative strategies in the foodprocessing industry in the Italian South". Entrepreneurship \& Regional Development 13

13. Bourdieu, Piere. 1986. The Form of Capital: Hand Book Theory and Research in Sociology of Education,. J.G.Richardson (edt), Wes Port, Green word Press.

14. Chen, Jia. 2006. Development of Chinese Small and Medium-Sized Enterprises. Journal of Small Business and Enterprise Development, Vol. 13 No.2, pp. 140-147

15. Chisholm, A. M., \& Nielsen, K. 2009. Social capital and the resource-based view of the firm. International Studies of Management and Organization, 39(2), 7-32.

16. Chowdhury. Mohammed S. 2007. Overcoming entrepreneurship development constraints: the case of Bangladesh. Journal of Enterprising Communities: People and Places in the Global Economy, Vol. 1 No.3, pp.240-251.

17. Cohen \& Prusak L. 2001. Social Capital In The Creation of Human Capital, The American Journal Of Sociology.

18. Coleman, James S. 1988. Social Capital in the Creation of Human Capital. The American Journal of Sociology, Vol.94, Supplement: Organizations and Institution: Sociological and Economic Approaches to the Analysis of Social Structure, pp. S95S120.

19. Cooper, R., Edget, S. and Kleinschmidt, E. 2004. Benchmarking Best NPD Practices I. Research Technology Management.

20. Covin, J \& D. Slevin.1989.Strategic Management of Small Firms in Hostile \& Benign Environments. Strategic Management Journal.

21. Cox, Eva. 1995. A Truly Civil Society (Lecture 2: Raising Social Capital). Boyer Lectures.

22. Croom. S.R., Brandon-Jones. A. 2007."Impact of E-procurement: experiences from implementation in the UK public sector". Journal of Purchasing \& Supply Management. Vol. 13. Hal. 294-303.

23. Cunningham JG. 2002. Textbook of Veterinary Physiology. Philadelphia (US): Saunders.

24. Davis et al. 2010. The Influence of CEO Gender on Market Orientation and Performance in Service Small and Medium-Sized Service Business. Small Business Management, 48(4), 475-496.

25. Diva, Gede. 2009. Mengembangkan UMKM Melalui Pemberdayaan Peran Pemerintah Daerah Bakrie School of Management: Jakarta.

26. Drucker, Peter F. 2008. Inovasi and Kewirausahaan Praktek and Dasar-Dasar. Jakarta: Penerbit Erlangga.

27. Durojaiye, AM. Yusuf S.A. Falusi A.O. and Okoruwa V O. 2013. Social Capital and Its Influence on Profitability of Foodstuff Traders in Southwestern Nigeria. American Journal Of Social And Management Sciences. Vol. 23, No.6.

28. Engkoswara, 1999, Menuju Indonesia Modern 2020. Bandung: Yayasan Amal Keluarga. 
29. Eraydin, Ayda and Bilge, Armatli-Köroğlu. 2005. Innovation, Networking and The New Industrial Clusters: The Characteristics of Networks and Local Innovation Capabilities in The Turkish Industrial Clusters. Entrepreneurship and Regional Development.Vol.17, 4, pp.237-266.

30. Farsi, J.Y. Rezazadeh. A. Najmabadi. A.D. 2013. Social Capital and Organizational Innovation: The Mediating Effect of Entrepreneurial Orientation. Journal of Community Positive Practices, XIII(2) 2013, 22-40.

31. Frishammar, J. and Horte, S. A. 2007."The Role of Market Orientation and Entrepreneurial Orientation for New Product Development Performance in Manufacturing Firms".Technology Analysis \& Strategic Management.

32. Fukuyama, Francis. 1995. Trust: Kebajikan Sosial and Penciptaan Kemakmuran. Yogyakarta: Penerbit Qalam.

33. 1999. The End of History and the Last Man: Kemenangan Kapitalisme and Demokrasi Liberal. Yogyakarta: Penerbit Qalam.

34. Geriya, I Wayan. 1995. Pariwisata \& Dinamika Kebudayaan Lokal, Nasional, Global. Denpasar: Upada Sastra.

35. Ghozali, Imam. 2011. "Aplikasi Analisis Multivariate Dengan Program SPSS". Semarang: Badan Penerbit Universitas Diponegoro.

36. Guest, D.E., Michie, J, Conway, N \& Sheehan, M. 2003. "Human resource management and corporate performance in the UK" dalam British Journal of Industrial Relations, 41

37. Hadiyati, Ernani. 2013. Kreativitas and Inovasi Berpengaruh Terhadap Kewirausahaan Usaha Kecil. Jurnal Manajemen and Kewirausahaan. Vol.13, NO. 1. Maret 2013.

38. Hall, Mark L.Lengnick and Cynthia A. 2003. Human Resource Management in the Knowledge Economy. Berret Koehler.

39. Hasbullah, Jousairi. 2006. Social Capital: Menuju Keunggulan Budaya Manusia Indonesia. Jakarta: MR-United Press.

40. Huang, K. P., \& Wang, K. Y. 2011. The moderating effect of social capital and environmental dynamism on the link between entrepreneurial orientation and resource acquisition, The journal of Quality and quantity, 47(3), 1617-1628.

41. Hubbard, R. Glenn, O'Brien Anthony Patrick and Rafferty Mattew. 2012. Macroeconomics. New Jersey: Pearson.

42. Inayah. 2012. Peranan Modal Sosial dalam Pembangunan. Ragam Jurnal Pengembangan Humaniora. Vol. 12 No. 1, April 2012.

43. Ireland, R.D., Hitt, M.A., and Sirmon,. D.G. 2003. A Model of Strategic Enterepreneurship: The Construct and Its Dimension, Journal of Management, 29 (6), 963-989.

44. Jhingan, M.L. 2007.Ekonomi Pembangunan and Perencanaan. Jakarta: Raja Grafindo Persada.

45. Kaasa, A. 2009. Effects of different dimensions of social capital on innovative activity, Evidence from Europe at the regional level. Technovation, 29,218-233.

46. Kate, W. and Durrance, J.C. 2008. Social Networks and Social Capital:Rethinking Theory in Community Informatics. The Journal of Community Informatics. Vol. 4, No. 3Khaira, Amalia Fachrudin. 2011. Analisis Pengaruh Struktur Modal, Ukuran Perusahaan, and Agency Cost Terhadap Kinerja Perusahaan. Jurnal Akuntansi and Keuangan Vol.13 Universitas Sumatra Utara.

47. Keats, Barbara W. and Hitt, Michael A. 1988. A Causal Model of Linkages Among Environmental Dimensions, Macro-Ornagizational Characteristics, and Performance, Academy of Management Journal, 31, 570-596.

48. Keputusan Presiden Tahun 80 tahun 2003 tentang Pengadaan Barang Jasa Pemerintah.

49. Korry, I Nyoman Sugawa, et al. 2013. The Role of Entrepreneurial Orientation in Mediating the Effect of Organizational Culture and Government Policy toward Business Performance (Case Study: Koperasi Unit Desa in Bali Province). International Journal of Business and Commerce. Vol. 2, No.12: pp.29-42. ISSN: 2225-2436. 
50. Kozlowski, S. W. J., \& Klein, K. J. 2000. "A multilevel approach to theory and research in organizations: Contextual, temporal, and emergent processes" .K. J. Klein \& S. W. J. Kozlowski (Eds.). Multilevel theory, research, and methods in organizations: Foundations, extensions, and new directions. San Francisco, CA: Jossey-Bass.

51. Lee, D.Y and Tsang, EW.K. 2001. The Effect of Entrepreneurial Personality, Background and Network Activities on Venture Growth, Journal of Management Studies. Vol .38.4: pp 583-602.

52. Lumpkin, G. T. and Dess, G. G. 1996. Clarifying the entrepreneurial orientation construct and linking itto performance. Academy of Management Review.

53. Luthans, F. 2005. Organizational Behavior. New York: McGraw-hill.

54. Mardikanto, Totok. 1993. Penyuluhan Pembangunan Pertanian. Surakarta: Sebelas Maret Univercity Press.

55. Miller, D. and P. Friesen. 1982. "Innovation in Conservative and Entrepreneurial Firms: Two Models of Strategic Momentum." Strategic Management Journal Vol. 3

56. 1984. A Longitudinal Study of the Corporate Life Cycle. Management Science 30.

57. Miles, M.P; Joe Giglierano and rob Vitale. 2003. Entrepreneurial Orientation, Market Orientation, and Performance in Established and startup Firms. Working Paper

58. Morris, Michael H \& Donald F. Kuratko. 2002. Corporate Entrepreneurship. United States of Amerika: South Western a division of Thomson Learning.

59. Mosher, A.T. 1965. Menggerakkan and Membangun Pertanian. C.V. Yasaguna.

60. Munizu, Musran. 2010. Pengaruh Faktor-Faktor Eksternal and Internal Terhadap Kinerja Usaha Mikro and Kecil (UMK) di Sulawesi Selatan. Jurnal Manajemen and Kewirausahaan, Vol.12, No. 1.

61. Mustafa. K.2010. Pengadaan Barang and Jasa di Pemerintahan (Bagian IV: EProcurement - Apa and Bagaimana). (cited 10 Desember 2015). Available from: http://www.khalidmustafa.info.

62. Mutchler, J. 1984. "Auditors Perceptions of the Going Concern Opinion Decision." Auditing: Journal Practise and Theory.

63. Naskah Akademik RUU pengadaan Barang/Jasa Negara Tahun 2015

64. Naudé, W.A., and M. Matthee. 2007. 'The Geographical Location of Manufacturing Exporters in South Africa', WIDER Research Paper 2007/09, Helsinki: UNU-WIDER.

65. Neely, A., Adams, C., \& Kennerley, M. 2002. The Performance Prism: The Scorecard for Measuring and Managing Business Success. London: Prentice Hall.

66. Nonaka, I., and Takeuchi, H. 1995. The Knowledge-Creating Company. New York: Oxford University Press

67. Nurlaila, 2010. Manajemen Sumber Daya Manusia I. Penerbit LepKhair

68. Ozsomer, A, Calantone, RJ, \& Di Benedetto, A. 1997. What makes firms more innovative? A look at organizational and environmental factors. Journal of Business \& Industrial Marketing.

69. Peraturan Kepala Lembaga Kebijakan Pengadaan Barang/Jasa Pemerintah (LKPP) nomor 1 tahun 2011 tentang Electronic Tendering.

70. Peraturan Presiden Nomor 16 Tahun 2018 Tentang Pengadaan Barang/Jasa Pemerintah.

71. Piazza-Georgi, B. 2002. The Role of Human and Social Capital in Growth: Extending Our Understanding. Cambridge. Journal of Economics. Vol. 26 (4). p 461-79.

72. Preffer, J. 1994. Competitive advantage through people. Boston: Harvard Business School Press.

73. Putnam R D. 1993. "The Prosperous Community: Social Capital and Public Life. The American of Prospect, Vol 13, pp 35-42.

74. Qian, Gongming and Li, Lee.2003. Profitability of small and medium-sized Enterprises in high-tech industries: the Case of the biotechnology industry. Strategic Management Journal Strat. Mgmt.J.

75. Rahab, Istiqomah, and Dian Purnomojati. 2009. Permodelan mengenai Peran Product Improvement and Process Improvement terhadap Kinerja UKM. Laporan Penelitian.Universitas Jenderal Soedirman. Purwokerto. 
76. Reswanda. 2011. Pengaruh Orientasi Kewirausahaan terhadap Pembelajaran Organisasi, Keunggulan Daya Saing Berkelanjutan and Kinerja Usaha pada UMKM Kerajinan Kulit Berorientasi Ekspor di Sidoarjo. Jurnal Disertasi. Universitas Airlangga.

77. Robinson, A. G. and Stern, S.2007. Corporate Creativity. SanFrancisco: BerrettKoehler.

78. Schiffer, M. \& Weder, B. 2001. Firm Size and the Business Environment: Worldwide Survey Results. Washington, DC: The World Bank.

79. Schmidt, F.L., Hunter, J.E., McKenzie, R.C. \& Muldrow, T.W. 1979. "Impact of valid selection procedures on work-force productivity". Journal of Applied Psychology 64.

80. Simamora. Yohanes Sogar. 2009. Hukum Perjanjian; Prinsip Hukum Kontrak Pengadaan Barang and Jasa Pemerintah. Yogyakarta: LaksBang Pressindo.

81. Slater, S.F. \& Narver, 1995, Marketing Orientation and Organizational Learning.Journal of Marketing.

82. Suhardiyono, L. 1992. Penyuluhan: Petunjuk Bagi Penyuluh Pertanian. Jakarta: Erlangga.

83. Sumarni. 2013. Intervensi Pemerintah Antara Kebutuhan and Penolakan di Bidang Ekonomi. Economica. Jurnal Program Studi Pendidikan Ekonomi. Vol. 1 No. 2, April 2013.

84. Suparta, N. 2005. Pendekatan Holistik Membangun Agribisnis. Denpasar: Bali Media Adhikarsa.

85. Tri Ratnawati, Andalan and Hikmah. 2010. Faktor-Faktor Yang Mempengaruhi Kinerja UKM (Studi Kasus UKM DI Kabupaten and Kota Semarang). Serat Acitya-Jurnal IImiah UNTAG Semarang, Vol. 7, No. 9.

86. Undang-Undang Nomer 8 tahun 2008 tentang Usaha Mikro, Kecil and Menengah.

87. Undang-Undang Republik Indonesia Nomor 20 Tahun 2008 Tentang Usaha Mikro, Kecil and Menengah.

88. Upton, D.M. 1995. "What really makes factories flexible?". Harvard Business Review 73.

89. Usvita, Mega. 2014. Pengaruh Orientasi Kewirausahaan and Orientasi Pasar Terhadap Kinerja Perusahaan Melalui Keunggulan Bersaing Sebagai Variabel Intervening (Survey Pada UKM Pangan Dinas Perindagtamben Kota Padang). eJournal Apresiasi Ekonomi. (3)1. Januari 2015: 31-37.

90. Venkatraman and Ramanujam. 1986. Measurement of Bussines Perfomance in Strategy Research: A Comparison of Approaches. Academy of Management Review, Vol 1.

91. Vitale R, Giglierano J, and Miles M. 2003." Entrepreneurial Orientation, Market Orientation, and Performance in Estableshed and Startup Firms. http://www.uic.edu/cba/ies/2003papers.

92. Wahyuni, Tri Endang. 2008. Upaya Menumbuhkembangkan Kewirausahaan di Kalangan Mahasiswa. AKMENIKA UPY. Volume 2.

93. Weerawardena, Jay. 2003. Exploring The Role of Market Learning Capability in Competitive Strategy. European Journal of Marketing, Vol.37,p.407-429.

94. Widodo, S. 2009. Proses transformasi pertanian and perubahan sosial pada masyarakat Samin di Bojonegoro. EMBRYO. Vol 6(1): 57-66.

95. Wiklund, J. and Shepherd, D. 2005. Entrepreneurial Orientation and Small Business Performance: A Configurational Approach. Journal of Business Venturin. 20, 71-91.

96. Wimba, I Gusti Ayu. 2015. Pengaruh Modal Sosial Terhadap Orientasi Kewirausahaan and Biaya Transaksi Untuk Meningkatkan Kinerja Usaha Pada UKM Kerajinan Kayu Di Provinsi Bali. Disertasi. Denpasar:Universitas Udayana.

97. Wolff, James and Pett, Timothy L. 2006. Small-Firm Performance: Modeling the Role of Product and Process Improvements. Journal of Small Business Management. Vol. 44, Issue 2, pp. 268-284.

98. World Trade Organization. 2005. Government Procurement: The Plurilateral Agreement Overview of the Agreement of Government Procurement. 
99. World Bank. 2003. Electronic Government Procurement (e-GP). World Bank Draft Strategy.

100. Zaenal, Abdul. 2012. UMKM Sebagai tulang Punggung Perekonomian Nasional. Bandung: Alfabeta.

101. Zahra, S. A., and Garvis, D. M. 2000. Entrepreneurship and firm performance: The moderating effect of international environmental hostility,. Journal of Business Venturing, 15(5), pp. 469-492.

102. 2000, Manufacturing Strategy and New Venture Performance: A Comparison of Independent and Corporate Ventures in the Biotechnology Industry. The Journal of High Technology Management Research.

103. 2002, "Absorptive Capacity: A Review, Reconceptualization, and Extension". Academy of Management Review, Vol. 27. 